Original Research Article

\title{
Self medication practice and associated factors at the regional hospital Bamenda, Cameroon: a prospective study
}

\author{
Gerald Ngo Teke ${ }^{1 *}$, Sirri Letisia Nde², Mary Bi Suh ${ }^{2}$
}

\author{
${ }^{1}$ Department of Biomedical \\ Sciences, ${ }^{2}$ Department of \\ Nursing/Midwifery, University \\ of Bamenda, P.O. Box 39, \\ Bambili, Cameroon
}

Received: 31 December 2016

Accepted: 02 February 2017

\section{*Correspondence to: \\ Dr. Gerald Ngo Teke, \\ Email:ngobob@yahoo.com}

Copyright: (C) the author(s), publisher and licensee Medip Academy. This is an openaccess article distributed under the terms of the Creative Commons Attribution NonCommercial License, which permits unrestricted noncommercial use, distribution, and reproduction in any medium, provided the original work is properly cited.

\begin{abstract}
Background: Due to paucity of studies on the prevalence and pattern of self medication among Cameroonians and particularly dwellers of Bamenda City, in this research was undertaken to study the practice of self-drug administration among adult out patients at the Regional Hospital Bamenda; identify potential factors influencing self-medication practices; sources of drugs and/or information about medications and finally the reasons for self-drug administration.
\end{abstract}

Methods: Participants (200) of age 18 years and above who came for external consultation during the study period were sampled conveniently after giving their consent. They were administered questionnaires on self-medication practices. Data was analyzed using SPSS version 19.0.

Results: The prevalence of self-medication in this study was $86.50 \%(173 / 200)$. The females were more involved in the practice of self-medication $(88.18 \%)$ than males $(85.54 \%)$. Participants from deferent occupations had used various classes of drugs through self initiative. Analgesics were most commonly used $(84.39 \%)$. This was followed by antimalarials $(52.60 \%)$ and antibiotics $(41.62 \%)$. While the least represented was the class of laxatives $(1.73 \%)$. The factors promoting self medication practices were mainly due to mild nature of illness $(36.50 \%)$ and longtime spent to see the doctor $(22.50 \%)$. The leading source of information on self-medication prescription and administration came from doctors $(78.61 \%)$ and pharmacists $(34.42 \%)$. Over the counter drugs were the most commonly purchased from private pharmacies $(76.88 \%)$.

Conclusions: Self-medication is an important health issue in this area. This study shows the necessity to educate the public on health education and make regulation of pharmacies in limiting self-medication practices.

Keywords: Self-medication, over the counter drugs, associated factors, private pharmacies and market vendors, Bamenda-Cameroon

\section{INTRODUCTION}

The perception of self-health management includes behaviors such as symptom evaluation, self-diagnosis, self-medication, illness prevention and health maintenance. ${ }^{1}$ Hence self-drug administration could be termed as the use of medications (pharmaceuticals or herbs) to treat health problem with no professional diagnosis or prescription. ${ }^{2,3}$ The latter persons here may be family members, especially where the treatment of children or the elderly is involved. ${ }^{4}$ Common selfmedication drugs include pain killers (analgesics), antimalarials, antibacterials and syrups for cough. ${ }^{5}$ It is documented that self-medication is economical and when administered appropriately and in a responsible manner with no professional prescription, it can help in the prevention and treatment of diseases. ${ }^{6}$

Though some people involved in self-medication may attest of its effectiveness when administered judiciously, others used medication incorrectly, with no appropriate direction and justification. Some researchers have documented that about $67.1 \%$ of adults in Jordan use antibiotics against common cold and cough. ${ }^{7}$ Drugs involved in self-medication practices have been reported to include both over the counter (OTC) drugs and prescribed drugs. Moreover some individuals supplement 
pharmaceutics by plant based products. ${ }^{6}$ Once drugs are administered inappropriately without knowledge of associated risks and contradictions, they may provoke potential deleterious and life-threatening effects. ${ }^{8-10}$ Besides harmful effects, self-medication, could cause microbial resistance to such drugs thereby precipitating the emergence of multiple resistant microorganisms making treatment difficult and hence increasing morbidity. ${ }^{2,11,12}$

Due to paucity of studies on the prevalence and pattern of self-medication among Cameroonians and those living within the city of Bamenda in particular this study was undertaken. This study carried out at the Regional Hospital Bamenda was aimed to determine the prevalence of self-medication among adult out patients; identify factors influencing the practice of self-drug administration; recognize sources of drugs for this practice; identify sources of information on self-drug administration; and checkout reasons for such practices.

\section{METHODS}

Design of the study was a cross sectional, descriptive and hospital based questionnaire survey.

\section{Study setting and population}

This research was carried out at the Regional Hospital Bamenda (RHB), Northwest Region, Cameroon. It is one of the 10 regional hospitals in Cameroon that serves as a second level referral hospital to the district hospitals and the polyclinics in the Northwest Region (NWR). It is situated at the Azire Health Area in the Bamenda Heath District. It serves as a teaching hospital to medical students, student nurses, laboratory science students and other students. This study included adults from 18years and above who came for external consultation during the study period that lasted from $25^{\text {th }}$ March- $27^{\text {th }}$ May 2016.

\section{Inclusion criteria}

Individuals aged from 18 years and above and who gave consent, those willing to partake in the study, and who can communicate at least through speaking or writing were included.

\section{Exclusion criteria}

Individuals who did not complete the questionnaire or returned blank questionnaires were excluded.

\section{Sample size calculation}

The following simple formula was used. ${ }^{13}$

$n=Z^{2} P(1-P) / d^{2}$

Where $n=$ sample size, $Z=Z$ statistic for a level of confidence $95 \%$, which was conventional, $Z$ value was
1.96, $P=$ expected prevalence or proportion (in proportion of one was $11.9 \%$, i.e. $P=0.119$ as reported in a similar study by Selvaraj et al, and $d=$ precision (in proportion of one was $5 \%$, i.e. 0.05 ). This gave us a minimum sample size of $161 .{ }^{14}$

\section{Study procedure}

A total of 215 adult out-patients were sampled using a convenience sampling method. At the study site, the purpose of the study was made known to the participants and matters relating to confidentiality were ascertained individually. Prepared informed consent forms were signed by the volunteers before the administration of questionnaires. The well-structured questionnaires were then served to collect data from the participants and the importance of honesty in their responses was emphasized. Respondents were given the opportunity to ask questions for details regarding the study. Upon completion, the questionnaires were collected by the researcher for entry verification. A total of 200 participants completely filled the questionnaires appropriately while 10 participants were dropped out because of incomplete information and 5 others deliberately decided to withdraw from the study.

\section{Data collection tool}

A well structured questionnaire with open and close ended questions was used to collect data. Six sections were included in the questionnaire (A, B, C, D, E and F). Section A, containing demographic characteristics, including gender, age, occupation, level of education, and marital status. Section B, assessing the extent of selfmedication practices. Section $C$, assessing the factors influencing self-medication practices. Section D, identifying the common classes of drugs and routes of administration used for self-medication. Section E, sources of information on drug administration. Section F, on the sources of drugs and use of information on drug's leaflet.

\section{Data analysis}

The data was analyzed with the help of SPSS version 19 . The prevalence of self-medication was calculated from generated descriptive analysis and frequency tables. Chisquare test of association was conducted for association of factors. Statistical significance was considered at a pvalue less than 0.05 .

\section{RESULTS}

\section{Socio-demographic characteristics}

There were totally 215 participants sampled in this study with 200 respondents fully admitted, making a response rate of $93.02 \%$. The prevalence of self medication was $86.50 \%(173 / 200)$. The females were more represented in this study (117/200) and they were more involved in the practice of self medication $(88.18 \%)$ than males 
$(85.54 \%)$. Majority of the respondents in all the age groups (ranging from 18 to above 58 years) were highly practicing self medication as indicated in Table 1. A similar observation was recorded for the different categories of occupation, level of education and marital status. All these socio-demographic characteristics were in association with self-drug administration as shown in Table 1.

Table 1: Socio-demographic characteristics and prevalence of self medication $(n=200)$.

\begin{tabular}{|c|c|c|c|c|}
\hline \multirow{2}{*}{$\begin{array}{l}\text { Socio- } \\
\text { demographic } \\
\text { characteristics }\end{array}$} & \multicolumn{2}{|c|}{$\begin{array}{l}\text { Prevalence of self } \\
\text { medication }\end{array}$} & \multirow[t]{2}{*}{$\begin{array}{l}\chi^{2} \\
\text { value }\end{array}$} & \multirow[t]{2}{*}{$\begin{array}{l}\mathbf{P} \\
\text { value }\end{array}$} \\
\hline & $\operatorname{Yes}(\%)$ & $\mathrm{No}(\%)$ & & \\
\hline \multicolumn{3}{|l|}{ Gender } & \multirow{4}{*}{0.015} & \multirow{4}{*}{0.901} \\
\hline Males & $71(85.54)$ & $12(14.46)$ & & \\
\hline Females & $102(88.18)$ & $15(10.26)$ & & \\
\hline Total & $173(86.50)$ & $27(13.50)$ & & \\
\hline \multicolumn{3}{|l|}{ Age (years) } & \multirow{6}{*}{3.374} & \multirow{6}{*}{0.497} \\
\hline $18-27$ & $63(81.82)$ & $14(18.18)$ & & \\
\hline $28-37$ & $53(88.33)$ & $7(11.67)$ & & \\
\hline $38-47$ & $35(88.74)$ & $4(10.26)$ & & \\
\hline $48-57$ & $9(100)$ & 0 & & \\
\hline$>58$ & $13(86.67)$ & $2(13.33)$ & & \\
\hline \multicolumn{3}{|l|}{ Occupation } & \multirow{3}{*}{9.001} & \multirow{3}{*}{0.029} \\
\hline Unemployed & $37(74)$ & $13(26)$ & & \\
\hline Employed & $136(68.00)$ & $14(32.00)$ & & \\
\hline \multicolumn{3}{|c|}{ Level of education } & \multirow{5}{*}{1.438} & \multirow{5}{*}{0.697} \\
\hline No education & $8(100)$ & 0 & & \\
\hline Primary & $35(85.37)$ & $6(14.63)$ & & \\
\hline Secondary & $69(85.19)$ & $12(14.81)$ & & \\
\hline University & $61(87.14)$ & $9(12.86)$ & & \\
\hline \multicolumn{3}{|l|}{ Marital status } & \multirow{3}{*}{0.282} & \multirow{3}{*}{0.963} \\
\hline Single & $78(39.00)$ & $12(61.00)$ & & \\
\hline Married & $95(47.5)$ & $15(52.5)$ & & \\
\hline
\end{tabular}

\section{Classes of common self medicated drugs}

From the results in Table 2, participants used self-medications of various classes of drugs. Generally, these participants from deferent occupation categories admitted having been exposed to medications of the given classes of drugs through self initiative.

Analgesics constitute the class of most commonly self-reported medications used by respondents (84.39\%). This was followed by antibiotics (41.62\%) and antimalarials $(52.60 \%)$ while the least represented was the class of laxatives $(1.73 \%)$.

The existed associations between occupation of participants and choice of self medicated drugs was not significant at $\mathrm{p}<0.05$.

\section{Factors promoting self-medication practices}

The factors promoting self-medication practices were mainly due to mild nature of illness $(36.50 \%)$ and longtime spent to see the doctor $(22.50 \%)$ as reported in Table 3. Some respondents indicated that for similar past diseases or symptoms they used old prescriptions $(15.00 \%)$.

Lack of money $(9.50 \%)$ and staying far from hospitals $(14.00 \%)$ were other considerable influencing factors. Generally, the age groups did not matter much regarding these factors that promote self medication since the $p$ values were greater than 0.05 .

Sources of information and drugs for self-drug administration and use of information on drug's leaflet

From the various sources of information on self-drug administration proposed to the participants, the doctor $(78.61 \%)$ was the leading source of information on self medication prescription and administration as shown in Table 4

This was followed by information obtained from pharmacists (34.42\%). A significant difference was found among the sources of information on self-drug administration and the attached frequency of participants at $\mathrm{p}<0.05$.

Table 2: Classes of common drugs associated with occupation of participants $(n=173)$.

\begin{tabular}{|llllll|}
\hline $\begin{array}{l}\text { Classes of common } \\
\text { self medicated drugs }\end{array}$ & Occupation of participants & & & Total reports $(\%)$ \\
\hline Antibiotics & 18 & Semployed & Self employed & Public sector & Private sector \\
\hline Analgesics & 36 & 27 & 16 & 11 & $72(41.62)$ \\
\hline Antimalarials & 19 & 64 & 26 & 20 & $146(84.39)$ \\
\hline Antacids & 8 & 37 & 20 & 15 & $91(52.60)$ \\
\hline Antitussive & 5 & 12 & 4 & 2 & $26(15.03)$ \\
\hline Traditional herbs & 0 & 11 & 8 & 4 & $28(16.18)$ \\
\hline Anthelminthics & 6 & 3 & 4 & 3 & $10(5.78)$ \\
\hline Laxatives & 1 & 2 & 3 & 3 & $14(8.10)$ \\
\hline$\chi 2$ value (p- value) & $177(0.081)$ & $72(0.230)$ & $54(0.256)$ & $63(0.243)$ & $3(1.73)$ \\
\hline
\end{tabular}


Table 3: Factors promoting self-medication practices against age groups of participants $(\mathbf{n}=\mathbf{2 0 0})$.

\begin{tabular}{|lllllllll|}
\hline $\begin{array}{l}\text { Factors promoting self- } \\
\text { medication practices }\end{array}$ & $\begin{array}{l}\text { Age groups (years) } \\
\mathbf{1 8 - 2 7}\end{array}$ & $\mathbf{2 8 - 3 7}$ & $\mathbf{3 8 - 4 7}$ & $\mathbf{4 8 - 5 7}$ & $\mathbf{5 8}$ and above & Total(\%) & $\chi 2$ value & P value \\
\hline $\begin{array}{l}\text { Longtime spent to see the } \\
\text { doctor }\end{array}$ & 17.00 & 12.00 & 12.00 & 2.00 & 2.00 & $45(22.50)$ & 10.00 & 0.265 \\
\hline Stay far from hospital & 7.00 & 13.00 & 4.00 & 1.00 & 3.00 & $28(14.00)$ & 20.00 & 0.22 \\
\hline No money & 9.00 & 7.00 & 1.00 & 1.00 & 1.00 & $19(9.50)$ & 10.00 & 0.265 \\
\hline No accessible health facility & 2.00 & 1.00 & 1.00 & .00 & 2.00 & $6(3.00)$ & 10.00 & 0.265 \\
\hline Ignorance & 2.00 & 6.00 & 3.00 & 0.00 & 1.00 & $12(6.00)$ & 20.00 & 0.22 \\
\hline Mild nature of illness & 30.00 & 22.00 & 13.00 & 4.00 & 4.00 & $73(36.50)$ & 15.00 & 0.241 \\
\hline $\begin{array}{l}\text { Treated a similar symptom } \\
\text { before }\end{array}$ & 9.00 & 11.00 & 8.00 & 1.00 & 1.00 & $30(15.00)$ & 15.00 & 0.241 \\
\hline $\begin{array}{l}\text { Had past left over } \\
\text { medications }\end{array}$ & 2.00 & 2.00 & 0.00 & 1.00 & 0.00 & $5(2.50)$ & 10.00 & 0.265 \\
\hline
\end{tabular}

Table 4: Sources of information, drugs and use of directions on drug's leaflet $(n=173)$.

\begin{tabular}{|c|c|c|c|c|}
\hline Variables & Frequency & & $\chi^{2}$ value & p-value \\
\hline & Yes $(\%)$ & No $(\%)$ & & \\
\hline \multicolumn{5}{|c|}{ Sources of information } \\
\hline Doctor (physician) & $136(78.61)$ & 37 (21.39) & \multirow{6}{*}{90.000} & \multirow{6}{*}{0.0001} \\
\hline Pharmacist & $63(36.42)$ & $110(63.58)$ & & \\
\hline Relative/friend & $25(14.45)$ & $148(85.55)$ & & \\
\hline Television/radio & $8(4.62)$ & $165(95.38)$ & & \\
\hline Internet & $6(3.47)$ & $167(96.53)$ & & \\
\hline Others & $2(1.16)$ & $171(98.84)$ & & \\
\hline \multicolumn{5}{|l|}{ Sources of drugs } \\
\hline Private pharmacy & $133(76.88)$ & $37(23.12)$ & \multirow{5}{*}{60.000} & \multirow{5}{*}{0.0001} \\
\hline Road side vendors & $56(32.37)$ & $174(67.63)$ & & \\
\hline Market vendors & $86(49.71)$ & $161(50.29)$ & & \\
\hline Medicine store & $18(10.40)$ & $192(89.60)$ & & \\
\hline Others & $21(12.14)$ & $179(87.86)$ & & \\
\hline \multicolumn{3}{|c|}{ Follow directions on drug's leaflet } & \multirow{5}{*}{36.000} & \multirow{5}{*}{0.0001} \\
\hline Always & 105 (60.69) & $68(39.31)$ & & \\
\hline Sometimes & $43(24.86)$ & $130(75.14)$ & & \\
\hline When i remember & $20(11.56)$ & $153(88.44)$ & & \\
\hline Never & $5(2.90)$ & $168(97.10)$ & & \\
\hline
\end{tabular}

Participants were required to give information regarding sources of drugs commonly used by self-medicaters and whether they followed indications on drug's leaflet (appropriate disease, dosage, contraindications etc.). Those having been involved in the practice of selfmedication before and during the study reported various sources of medications as reported in Table 4. Over the counter drugs bought from private pharmacies constituted the most common source of self-drug administration $(76.88 \%)$. This was followed by market vendors $(49.71 \%)$ and road side vendors $(32.37 \%)$ which were weaker sources of self- medicated dugs. Those who obtained medications from other sources (traditional dealers, family members or friends) were about oneeighth of respondents who practice self-medication $(12.14 \%)$.
Out of the 173 participants who practiced self medication in this study, majority of them $(60.69 \%)$ always follow directions on drug's leaflet according to the manufacturer as indicated in Table 4. Some self medicaters at times $(24.86 \%)$ spare time to read indications on the medications they bought. Though it was observed that a small proportion of participants (11.56\%) read the indications on medication administration only when they remember yet some patients $(2.9 \%)$ never care to check the directions for drug use.

\section{DISCUSSION}

This study had the following as objectives: determination of self-medication prevalence at the RHB, identifying factors promoting self-medication practices, highlighting 
the common classes of medications used by selfmedicaters, and identifying sources of these medications and related information on their use. The act of selfmedication involves the use of drugs without any prescription from a specialist. ${ }^{15}$

The prevalence of self-medication in our study was $86.50 \%$. The range of self-medication practices as indicated in various studies is very wide and between $15 \%$ to $80 \% .{ }^{16-18}$ Some of the reasons accounting for these wide variations include differences in educational levels, econonomic status, and lack of health structures and availability of over the counter drugs.

The number of female participants reported herein outnumbered the males and with a corresponding higher prevalence of self-medication. This finding corroborates those of though at the same time contradicts the findings of other researchers. ${ }^{2,8,19,20}$ This could be due to the act that males spend less time in hospitals and concentrate at their job site so as to minimize loss of wages. In this light, they neglect mild illnesses. Being a hospital based survey; more women were present at the time of study. Moreover, in some cultures, women might be restricted to move freely outside the house and so decreases the trend to sought assistance from specialists and opt to selfmedicate until the illness can no longer be self managed. Women, especially mothers of under-five children, have been reported to commonly practice self-medication in response to their childhood ailments. ${ }^{21}$

In our study, the younger participants were more exposed to the practice of self-medicadtion than the older patients. This finding is consistent with the reports from other studies. ${ }^{14,20,22,23}$ One of the reasons for a high prevalence of self-medicaters among the youths could be their carefree attitude.

Most of these youths had attained secondary education and/or the university level. It is understood that the participant's educational level has a significant impact on self-medication practices though in our findings education was not a significant reason in the prediction of self-medication practices. The practice of self-drug administration is known to be global especially in urban and educated population. ${ }^{4}$ Probably the youths belief that they have learned enough to procure dugs, read and understand the indications for use. This result contradicts previous research. $^{24,25}$

Out of all the identified occupations, significant higher proportions of participants who self-medicated were self employed (involved in petit businesses) or wok in the public sector. In this study, use of self-medication was more common among socioeconomically better off compared to respondents who still depend strongly on others (students and housewives). Threat by loss in opportunity cost from loss of earnings would account for the higher prevalence of self-medication among financially viable participants. ${ }^{14}$ In general, the demographic characteristics reported in this study were found to be associated to the prevalence of self medication contrary to the findings of other authors. ${ }^{2,8,26}$

In this study most of the factors promoting selfmedication practices identified by respondents included mild nature of illness, longtime spent to see the doctor, staying far from hospital, no money, ignorance and no accessible health facility. These findings are similar to those reported in previous research. ${ }^{19,20,27-29}$ Moreover, quality health services are provided when the health facility is at proximity to the population and the cost of treatment being affordable to all if not free of charge.

Monetary constraints have been sighted as one of the major causes of self-medication practice. ${ }^{16,30}$ According to WHO, self medication is a less expensive measure for the poor especially those with low income.

As found in our study, $76.88 \%$ of respondents involved in self-medication indicated that the major source of drugs came from private pharmacies. This finding is consistent with previous work reported by other authors, indicating that pharmacies play a major role in the wide prevalence of self-medication among the population. ${ }^{31-34}$ In our country the government encourages the implantation of private pharmacies even at the community levels so as to limit the sales of medicines by road side and market drug vendors. This situation makes community pharmacies more generally considered the main source of drugs with no medical consultation. However, a considerable number of participants still obtained OTC drugs from road side and market drug vendors. Drugs from the medicine store were less solicited. This was contrary to other findings. ${ }^{2}$ The main source of medications used for self-drug administration by respondents came from medicine stores.

The important sources of information regarding use of drugs are physicians, pharmacists and relatives/friends. Some of the participants indicated the media (television/radio and internet) as source of information. Using the media (television/radio and internet) to advertise drugs and promote best drug use practices can be a powerful means to give impetus to self-medication. Some researchers have observed that the more pharmaceuticals are advertised the incease in number of those who self medicate in the population..$^{21,35}$ It is important to carefully design drug related advertisement in order to reduce self-medication practices. It is seen in our study that majority of those who self medicate were educated. Our results corroborates with the findings of Rushi. ${ }^{4}$ Thanks to this, most of those who self-medicated and who bought drugs from pharmacies were given some information on drug use (time of drug administration, food or other medications to avoid) by the dispensers. The worrisome issue here is that some of the selfmedicaters do not spare time to read indications on drug use from the leaflet. Medicines procured from a market 
vendor (whose prescription is doubtful) with no recall of posology implies patient will guess any dose at home.

Generally in the present study, the unemployed and self employed took antibiotics, analgesics, antimalarials, more frequently than did those of the public and private sectors before seeking urgency treatment. Therefore, there is need to strengthen education on the use of drugs, particularly for patients who are not financially viable. Antibiotics like amoxicillin, penicillin and other related derivatives have been shown to effectively inhibit a wide range of both aerobic and anaerobic bacteria. ${ }^{36,37}$

Our study found out that $41.62 \%$ of the participants took antibiotics without prior medical consultation. In other countries, antibiotics use in self-medication was reported (47.8\% in Southern China, $79.5 \%$ in Sudan and $48 \%$ in Iran. ${ }^{27,38,39}$ Self-medication with antimalarial drugs was recorded for above $50 \%$ of the respondents at the Regional Hospital Bamenda-Cameroon. This finding corroborates with other studies showing that the antimalarials and antibiotics are common medications used by self-medicaters. ${ }^{2,5}$ There is risk of drug misuse due to availability of these drugs used against malaria and other diseases of microbial origin. Moreover, not only the morbidity rate would increase but also the microbial resistant strains may eventually emerge making treatment difficult and costly. ${ }^{11,12,40}$

In this study, some patients reported of using drugs from alternative medicine (traditional herbs) probably because of experience and its free availability. The curative potentials of ayurvedic therapy since time immemorial is well documented. ${ }^{4}$ This finding is not surprising since almost the entire population of Cameroon is not eligible for free public health services regarding common diseases.

\section{CONCLUSION}

The prevalence of self-medication is high and constitutes an important health issue in this area. Our study shows the necessity of health education for health care providers, pharmacists and others, including parents, and regulation of pharmacies in limiting the practices of selfmedication. Emphasis should be on the risks associated with self diagnosis and treatment of minor ailments and indiscriminate use of over the counter drugs.

\section{ACKNOWLEDGMENTS}

The authors are grateful to the participants who voluntarily took part in this study.

\section{Funding: No funding sources}

Conflict of interest: None declared

Ethical approval: The study was approved by the Institutional Ethics Committee of North West Regional Delegate of Public Health and the Regional Hospital Bamenda

\section{REFERENCES}

1. Jesús S. Self-medication practices among a sample of Latino migrant workers in South Florida. Frontiers in Public Health. 2014;1-7.

2. Osemene KP, Lamikanra A. A Study of the Prevalence of Self-Medication Practice among University Students in Southwestern Nigeria. Tropical Journal of Pharmaceutical Research. 2012;11:683-9.

3. Hernandez-Juyol M, Job-Quesada JR. Dentistry and self-medication: A current challenge. Med Oral. 2002;7:344-7.

4. Rushi NP, Kunal SJ, Falgun IV, Varsha JP. Prevalence, pattern and perceptions of selfmedication in medical students. International Journal of Basic \& Clinical Pharmacology. 2013;2(3):275-80.

5. Afolabi AO. Factors influencing the pattern of selfedication in an adult Nigerian population. Ann Afr Med. 2000;7(3):120-7.

6. World Health Organization: The role of the pharmacist in self-care and self-medication. In Report of the 4th WHO Consultative Group on the Role of the Pharmacist in Health Care System. Geneva: WHO; 1998.

7. Shehadeh M, Suaifan G, Darwish RM, Wazaify M, Zaru L, Alja'fari S. Knowledge, attitudes and behavior regarding antibiotics use and misuse among adults in the community of Jordan. A pilot study. Saudi Pharmaceut J. 2012;20(2):125-33.

8. Shah SJ, Hamna A, Rija BR, Sidra N, Mirrah M, Muhammad HJ, et al. Self-medication with antibiotics among non-medical university students of Karachi: a cross-sectional study. BMC Pharmacology and Toxicology. 2014;15:74.

9. Okeke NI, Lamikanra A, Edelman R. Socioeconomic and Behavioral Factors Leading to Acquired Bacterial Resistance to Antibiotics in Developing Countries. Emerg Infect Dis. 1999;5(1):18-27.

10. Sanghani S, Zaveri HG, Patel VJ. Self medication: Prevalence and Pattern in urban community. J Pharmacovigilance Drug Safety. 2008;5:95-8.

11. Okeke NI, Lamikanra A, Edelman R. Socioeconomic and Behavioral Factors Leading to Acquired Bacterial Resistance to Antibiotics in Developing Countries. Emerg Infect Dis. 1999;5(1):18-27.

12. Fadara JO, Tamuno I. Antibiotic Self-medication among university medical undergraduates in Northern Nigeria. J. Pub Health Epidemiol. 2011;3(5):217-20.

13. Daniel WW. Biostatistics: A Foundation for Analysis in the Health Sciences. 7th edition. New York: John Wiley \& Sons; 1999.

14. Selvaraj KSK, Ramalingam A. Prevalence of selfmedication practices and its associated factors in Urban Puducherry, India. Perspect Clin Res. 2014;5:32-6.

15. Albarrán KF, Zapata LV. Analysis and quantifiation of self-medication patterns of customers in 
community pharmacies in southern Chile. Pharm World Sci. 2008;30:863-8.

16. Pankaj G, Prateeks B, Saurabh RS. Determinants of self medication practices in an urban slum community. Asian Journal of Pharmaceutical and Clinical Research. 2011;4(3):54-7.

17. Lal V, Goswami A, Anand K. Self-medication among residents of urban resettlement colony, New Delhi. Indian J Public Health. 2007;51(4):249-51.

18. Afola AO. Factors influencing the pattern of seilfmedication in an adult Nigerian population. Annals of African Medicine. 2007;7(3):120-7.

19. Carrasco-Garrido P, Jiménez-García R, Barrera VH, Gil de Miguel A. Predictive factors of self-medicated drug use among the Spanish adult population. Pharmacoepidemiology and Drug Safety. 2008,17:193-9.

20. Alghanim SA. Self-medication practice among patients in a public health care system. Eastern Mediterranean Health Journal. 2011;17(5):409-16.

21. Kabiru KS, Olubukola JA. The practice of selfmedication for treatment of illnesses for under-five children by mothers in Ibadan, Nigeria. Research Journal of Drug Abuse. 2015;2(2):1-7.

22. Linden M, Wurzendorf K, Ploch M, Schaefer M. Self medication with St. John's wort in depressive disorders: an observational study in community pharmacies. Journal of Affective Disorders. 2008,107:205-10.

23. Pavan KK, Maseer K, Chandrasekhar A. Self medication practices among urban slum dwellers in south Indian city. International Journal of Pharma and BioSciences. 2012;3(3):81-7.

24. Saeed AA. Self-medication among primary care patients in Farazdak Clinic in Riyadh. Social Science \& Medicine. 1988;27:287-9.

25. Awad A, Eltayeb I, Matowe L, Thalib L. Selfmedication with antibiotics and antimalarials in the community of Khartoum State, Sudan. Journal of Pharmacy and Pharmaceutical Sciences. 2005;8:32631.

26. Shehnaz SI, Khan N, Sreedharan J, Issa KJ, Arifulla M. Self-medication and related health complaints among expatriate high school students in the United Arab Emirates. Pharmacy Pract. 2013;11(4):211-8.

27. Awad AI, Eltayeb IB. Self-medication practices with antibiotics and antimalarials among Sudanese undergraduate university students. Ann Pharmacother. 2007;41(7-8):1249-55.

28. Abay SM, Amelo W. Assessment of Self-Medication Practices Among Medical, Pharmacy, and Health Science Students in Gondar University, Ethiopia. Journal of Young Pharmacist. 2010;2(3):306-10.
29. Fuentes AK, Villa ZL. Analysis and quantification of self-medication patterns of customers in community pharmacies in southern Chile. Pharmacy World and Science. 2008;30:863-8.

30. Phalke VD, Phalke DB, Durgawale PM. SelfMedication Practices in Rural Maharashtra. Indian Journal of Community Medicine. 2006;31(1):34-5.

31. Sallam SA, Khallafallah NM, Ibrahim NK, Okasha AO. Pharmacoepidemiological study of selfmedication in adults attending pharmacies in Alexandria, Egypt. Eastern Mediterranean Health Journal. 2009;15:683-91.

32. Sawalha AF. A descriptive study of self-medication practices among Palestinian medical and nonmedical university students. Research in Social and Administrative Pharmacy. 2008;4:164-72.

33. Awad AI, Eltayeb IB, Capps PA. Self-medication practices in Khartoum State, Sudan. European Journal of Clinical Pharmacology. 2006;62:317-24.

34. Yousef AM, Al-Bakri AG, Bustanji Y, Wazaify M. Self-medication patterns in Amman, Jordan. Pharmacy World and Science. 2008;30:24-30.

35. Burak LJ, Damico A. College students' use of widely advertied medicatins. J Am Coll Health. 2000;49:118-21.

36. De-Paula KB, Silveira LS, Fagundes GX, Ferreira MBC, Montagner F. Patient automedication and professional prescription pattern in an urgency service in Brazil. Braz Oral Res. 2014;28(1):1-6.

37. Gomes BP, Jacinto RC, Montagner F, Sousa EL, Ferraz CC. Analysis of the antimicrobial susceptibility of anaerobic bacteria isolated from endodontic infections in Brazil during a period of nine years. J Endod. 2011;37(8):1058-62.

38. Pan H, Cui B, Zhang D, Farrar J, Law F, Ba-Thein W. Prior knowledge, older age, and higher allowance are risk factors for self-medication with antibiotics among university students in southern China. PloS One. 2012;7(7):e41314.

39. Sarahroodi S, Arzi A, Sawalha A, Ashtarinezhad A. Antibiotics self-medication among Southern Iranian University students. Intern J Pharmacol. 2010;6(1):48-52.

40. Aswapokee N, Vaithayapichet S, Heller RF. Pattern of antibiotic use in medical wards of a university hospital, Bankok, Thailand. Rev Infect Dis. 1990;12(1):136-41.

Cite this article as: Teke GN, Nde SL, Suh MB. Self medication practice and associated factors at the regional hospital Bamenda, Cameroon: a prospective study. Int J Basic Clin Pharmacol 2017;6:1560-6. 